\title{
VOCATIONAL PURPOSEFULNESS OF YOUNG PEOPLE IN RURAL COMMUNITIES: THE SIGNIFICANCE OF SOCIO-ENVIRONMENT FACTORS
}

\author{
Kristina KOVALČIKIENĖ, Department of Philosophy, Psychology and Vocational Education, Centre for Cultural Communication \\ and Education,Aleksandras Stulginskis University, Universiteto st. 10, LT-53361 Akademija, Kaunas district, Lithuania, \\ kristina.kovalcikiene@asu.lt (corresponding author) \\ Sonata MILUSAUSKIENE, New Ūtos Library, Naujoji Ūta, LT-59260 Prienai distr., Lithuania; sonata9ster@gmail.com
}

\begin{abstract}
The development of rural businesses and the implementation of innovations in rural areas depends on possibilities to realize individual's potential, and the opportunities to develop initiative and creativity of young people. The aim of the study was to reveal the significance of socio-environment factors for the vocational decision making of senior pupils from secondary school in rural areas. The factors were analyzed from the viewpoint of senior pupils and members of rural community. The object of the research - the socio-environment factors of vocational purposefulness of young people in rural communities. The research tasks focus on the attitudes of rural community members and young people toward factors that influence the vocational purposefulness of youth in rural areas. Also, the differences between two groups were analyzed. The sample consisted of 280 respondents: 100 secondary school senior pupils (56\% girls and $44 \%$ boys, the mean age - 16 years) and 180 rural community members ( $80 \%$ women and $20 \%$ men, 35 years old in average). Based on the works of researchers in the area of vocational orientation and purposefulness, the questionnaire was compiled. The results revealed that socio-environment factors are important for the purposeful decision making on the vocational choice of youth in rural areas. From the view point of rural community members, the main factors are: family traditions, the profession's prestige in society, the influence of parents, friends and important others, and family conditions. According to the opinion of senior pupils from secondary school, the important factors are: family conditions and traditions, friends and other important people, as well as profession status in the rural community. Recommendations for development of young people's vocational purposefulness in rural areas are presented.
\end{abstract}

Keywords: rural community, socio-environment factors, vocational decision making, senior pupils, youth

\section{INTRODUCTION}

Young people are ones who are the future initiators of innovations and business in rural regions. P. E. Rao and G. J. Rao (2014) argued that the development of rural areas is the source of economic growth and the contribution of youth in rural development is emphasized. However, the decline in workforce and aging populations are real threats, the rural regions may face in the near future (Chiritescu, et al., 2015). Rural adolescents approach the transition out of high school with individual concerns about making an emotionally or financially expensive "mistake", family concerns about young people leaving home, and national and local concerns about declining rural economies and out-migration (San Antonio, 2016; Simoes et al., 2017). On the other hand, nowadays there is a tendency in Lithuania that more and more people are going to live in the countryside. In both cases, it is therefore very important to help young people to choose the right path regarding their future career.

Profession is chosen for lifetime, so it is important that young people would make a right decision. Vocation determines person's self-concept, self-awareness, self-respect, as well as generates income, etc. From the persons' perspective, regardless of the place of residence (rural or urban), the process of career choosing mainly rely on young people's personal interests, aptitudes, individual psychological characteristics (Mubarakshevna, Kasymovna, 2014).

Purposeful vocational decision is the most important task of adolescence-end and early youth period (Sajienè, Antanaitienè, 2012). Thus, it is meaningful to analyze the factors that are important for purposeful decision making on the vocational choice in rural areas. Constantly changing social-cultural environment, education, medicine, human relations, etc. provides people with new opportunities, but also it causes difficulties that are being addressed by joining rural communities. Community based education are those learning activities that make use of the community as a learning environment and might have a potential effect on choice of career or willingness to work in rural areas later on (Amalba et al., 2017; Kojo Edeme, Akpotohwo, 2016; Lee, Lee, 2015; Yao, 2017). Rural community, as an important factor Therefore, it is assumed that rural communities and related socio-environment factors plays an essential role when vocational choices of youth are considered.

Copyright (C) 2017 The Authors. Published by Aleksandras Stulginskis University. This is an open-access article distributed under the terms of the Creative Commons Attribution License (CC-BY 4.0), which permits unrestricted use, distribution, and reproduction in any medium, provided the original author and source are credited. 
Although, there is some research conducted on factors influencing choice of profession in Lithuania, there is a lack of such studies in rural regions and rural community, as one of the career choice factors, has not been evaluated yet. Professional orientation of senior pupils' education is important also in the process of education management: planning and organization, because the more detailed the information possessed by people who make decisions, the more probable it may be that people will be more aware of their choices. That is why this research may be interesting and useful for managers of educational institutions, but also for teachers, class tutors, parents, members of rural communities, and others who care about youth's future in rural areas.

The aim of the study is to reveal the significance of socio-environment factors for the vocational decision making of senior pupils from secondary school in rural areas. Research hypothesis: the socio-environment factors has a role for purposeful decision making on the vocational choice in rural communities. The object of the research - the socioenvironment factors of vocational purposefulness of young people in rural communities.

The research tasks:

1. To analyze the attitudes of rural community members toward factors that influence the vocational purposefulness of young people in rural communities.

2. To analyze the attitudes of young people in rural communities toward factors that determine their vocational purposefulness.

3. To compare the attitudes of young people and community members toward professional purposefulness of youth in rural areas.

In order to achieve the goal and tasks formulated, the methods used in this research: scientific literature analysis; questionnaire survey of rural community members; questionnaire survey of senior pupils; statistical analysis of data.

\section{METHODS}

\section{Participants and procedure}

In order to investigate the opinion of senior pupils and members of rural communities regarding socio-environment factors that are important for young people in rural areas to make a purposeful vocational decision, a questionnaire survey was conducted. The research was carried out in rural communities of Pasvalys and Prienai districts. The sample consisted of 280 respondents: 100 secondary school senior pupils (56\% girls and 44\% boys, mean age - 16 years) and 180 community members ( $80 \%$ women and $20 \%$ men, 35 years old in average). 120 questionnaires were distributed to the pupils of older classes, of which 100 filled out questionnaires were returned (83\%). 200 questionnaires were distributed to members of rural communities, of which 180 completed questionnaires were returned (90\%). All respondents participated voluntarily in the research. A part of the results of a larger study are presented in this article.

\section{Measures}

Based on the works of L. Jovaiša, S. Kregždè, R. Adamonienè, S. Daukilas and colleagues, K. Pukelis and other researchers in the area of vocational orientation and purposefulness, the questionnaire was compiled. The study is quantitative, the type of the questions is closed and open, with several options for each closed questions and opportunity for participants to express their opinions in open-ended questions. The questionnaire survey aims to find out the demographic data of the respondents, as well as the opinion of the respondents regarding factors in rural areas that have a major importance on the purposeful decision making on the vocational choice for senior pupils.

\section{RESULTS}

Chi-Square Tests analysis was conducted to compare the importance of socio-environment factors for youth's purposeful decision making on the vocational choice among rural community and senior pupils. The results of the importance of the profession in family is presented in Table 1. The results indicated that the role of the profession in the family is more valued by the rural community compared to senior pupils $(\mathrm{p}<0.001)$.

Table 1. Results of Chi-Square Tests analysis for socio-environment factors: family

\begin{tabular}{|c|c|c|c|c|c|c|}
\hline \multirow{2}{*}{\multicolumn{2}{|c|}{ The importance of the profession in family }} & \multicolumn{2}{|c|}{ Family importance } & \multirow{2}{*}{$\chi^{2}$} & \multirow{2}{*}{ df } & \multirow{2}{*}{ Sig. } \\
\hline & & Community & Senior pupils & & & \\
\hline Not important & Count $(\%)$ & $10(5.6 \%)$ & $10(10.0 \%)$ & & & \\
\hline Partly important & Count (\%) & $3(1.7 \%)$ & $29(29.0 \%)$ & 51.775 & 2 & $p<.001$ \\
\hline Important & Count (\%) & $167(92.8 \%)$ & $61(61.0 \%)$ & & & \\
\hline
\end{tabular}

Second important socio-environment factor for young people's vocational decision making is the importance of the profession in society (see Table 2). The results indicated that most of the rural community members (48.9\%) evaluate this factor as important. While most of the senior pupils (44\%) are not sure about the importance of this factor. The differences are statistically significant $(\mathrm{p}<.05)$.

Table 2. Results of Chi-Square Tests analysis for socio-environment factors: society

\begin{tabular}{|c|c|c|c|c|c|c|}
\hline \multirow{2}{*}{\multicolumn{2}{|c|}{ The importance of the profession in society }} & \multicolumn{2}{|c|}{ Society importance } & \multirow{2}{*}{$\chi^{2}$} & \multirow{2}{*}{ df } & \multirow{2}{*}{ Sig. } \\
\hline & & Community & Senior pupils & & & \\
\hline Not important & Count (\%) & $47(26.1 \%)$ & $15(15.0 \%)$ & \multirow{3}{*}{11.754} & \multirow{3}{*}{2} & \multirow{3}{*}{.003} \\
\hline Partly important & Count (\%) & $45(25.0 \%)$ & $44(44.0 \%)$ & & & \\
\hline Important & Count (\%) & $88(48.9 \%)$ & $41(41.0 \%)$ & & & \\
\hline
\end{tabular}


In analyzing the importance of the profession status in the rural community (see Table 3 ), $41.7 \%$ of rural community revealed that this factor is not important at all. However, more than half of young people in rural areas who participated in the research indicated that this factor is significant for them $(\mathrm{p}<.001)$.

Table 3. Results of Chi-Square Tests analysis for socio-environment factors: rural community

\begin{tabular}{|c|c|c|c|c|c|c|}
\hline \multirow{2}{*}{\multicolumn{2}{|c|}{ The importance of the profession status in the rural community }} & \multicolumn{2}{|c|}{ Rural community importance } & \multirow{2}{*}{$\chi^{2}$} & \multirow[b]{2}{*}{ df } & \multirow{2}{*}{ Sig. } \\
\hline & & Community & Senior pupils & & & \\
\hline Not important & Count $(\%)$ & $75(41.7 \%)$ & $15(15.0 \%)$ & \multirow{3}{*}{21.300} & \multirow{3}{*}{2} & \multirow{3}{*}{$\mathrm{p}<.001$} \\
\hline Partly important & Count $(\%)$ & $33(18.3 \%)$ & $30(30.0 \%)$ & & & \\
\hline Important & Count $(\%)$ & $72(40.0 \%)$ & $55(55.0 \%)$ & & & \\
\hline
\end{tabular}

Most of the rural community members (70\%) think that friends and important others in young people's life is an important factor for vocational decision making (see Table 4). While young people were not so sure. 52\% of them indicated that the influence of friends and acquaintances is important and $30 \%$ said that the importance is partial.

Table 4. Results of Chi-Square Tests analysis for socio-environment factors: friends and important others

\begin{tabular}{|c|c|c|c|c|c|c|}
\hline \multirow{2}{*}{\multicolumn{2}{|c|}{ The influence of friends, acquaintances }} & \multicolumn{2}{|c|}{ Friends, acquaintances importance } & \multirow{2}{*}{$\chi^{2}$} & \multirow[b]{2}{*}{ df } & \multirow{2}{*}{ Sig. } \\
\hline & & Community & Senior pupils & & & \\
\hline Not important & Count $(\%)$ & $42(23.3 \%)$ & $18(18.0 \%)$ & \multirow{3}{*}{51.775} & \multirow{3}{*}{2} & \multirow{3}{*}{$\mathrm{p}<.001$} \\
\hline Partly important & Count (\%) & $12(6.7 \%)$ & $30(30.0 \%)$ & & & \\
\hline Important & Count $(\%)$ & $126(70.0 \%)$ & $52(52.0 \%)$ & & & \\
\hline
\end{tabular}

Evaluations of family condition factor are presented in Table 5. The results indicated that most of the rural community members $(86.1 \%)$ see this factor as important for senior pupils' vocational decision making. Also, most of the senior pupils $(66 \%)$ agree to this, but one third of them think that family condicions are partly important $(26 \%)$ or not important at all $(8 \%)$.

Table 5. Results of Chi-Square Tests analysis for socio-environment factors: family conditions

\begin{tabular}{|c|c|c|c|c|c|c|}
\hline \multirow{2}{*}{\multicolumn{2}{|c|}{ The importance of family conditions }} & \multicolumn{2}{|c|}{ Family conditions importance } & \multirow[b]{2}{*}{$\chi^{2}$} & \multirow[b]{2}{*}{$\mathrm{df}$} & \multirow[b]{2}{*}{ Sig. } \\
\hline & & Community & Senior pupils & & & \\
\hline Not important & Count $(\%)$ & $15(8.3 \%)$ & $8(8.0 \%)$ & \multirow{3}{*}{24.202} & \multirow{3}{*}{2} & \multirow{3}{*}{ p<.001 } \\
\hline Partly important & Count $(\%)$ & $10(5.6 \%)$ & $26(26.0 \%)$ & & & \\
\hline Important & Count (\%) & $155(86.1 \%)$ & $66(66.0 \%)$ & & & \\
\hline
\end{tabular}

The role of school and school activities was analyzed as socio-environment factor in rural areas for youth's purposeful decision making regarding their vocation. The results are presented in Table 6 . The results indicated that there are no significant differences between scores of rural community members and senior pupils. However, the results surprised that only less than half of the senior pupils in rural areas described this factor as important.

Table 6. Results of Chi-Square Tests analysis for socio-environment factors: school activities

\begin{tabular}{|c|c|c|c|c|c|c|}
\hline \multirow{2}{*}{\multicolumn{2}{|c|}{ The importance of school activities }} & \multicolumn{2}{|c|}{ School activities importance } & \multirow{2}{*}{$\chi^{2}$} & \multirow{2}{*}{$\mathrm{df}$} & \multirow{2}{*}{ Sig. } \\
\hline & & Community & Senior pupils & & & \\
\hline Not important & Count $(\%)$ & $30(16.7 \%)$ & $23(23.0 \%)$ & \multirow{3}{*}{2.464} & \multirow{3}{*}{2} & \multirow{3}{*}{.292} \\
\hline Partly important & Count (\%) & $57(31.7 \%)$ & $34(34.0 \%)$ & & & \\
\hline Important & Count (\%) & $93(51.7 \%)$ & $43(43.0 \%)$ & & & \\
\hline
\end{tabular}

These results suggest that the evaluation scores of socio-environment factors were higher of rural community members compared with rural senior pupils. However, the above mentioned factors are important for young people's vocational decision making in rural areas.

\section{DISCUSSION}

The aim of the study was to reveal the significance of socio-environment factors for purposeful decision making on the vocational choice of senior pupils from secondary school in rural areas. Summarizing the results of the quantitative research, it can be stated that socio-environment factors are important for the vocational decision making of senior pupils. Moreover, the differences between the evaluations of senior pupils and the rural community members are significant. From the view point of rural community members, the main factors are: family traditions, the profession's prestige in society, family conditions, the influence of parents, friends and important others. According to the opinion of senior pupils, the important factors are: family conditions and traditions, friends and other important people, as well as profession status in the rural community. Interesting, that only less than half of the senior pupils in rural areas revealed the importance of school and its activities. It is important to strengthen the role of schools in rural areas. It is also recommended to initiate more activities related to young people's vocational decision making. Rural schools should offer various activities for their students not only for purposeful decision making on vocational choice but also to provide them with a competitive edge in the job market (O’Neill, 2013). The main factors that influence vocational choice are social-economical (living environment, social, economic and cultural family state, science and technical progress, general economic situation, 
earnings, etc.), pedagogical (purposeful education during lessons, sessions of extra education, extracurricular and public activity and it's results: knowledge, abilities, values), psychological (needs, interests, bents, general and special abilities, intellect, character, value orientations) (Sajienè, Antanaitienè, 2012).

Family conditions and family traditions are the most important factor for youth in vocational decision making process. It can be argued that the socioeconomic and educational environment at home is important for children's learning motivation, which determines the professional orientation of the person. It means that family life and particular situation, education and occupation of parents, material conditions, recognized values, etc., are determinants of purposeful vocational choice. These results confirm the results of other studies that emphasizes the importance of the family for rural adolescents concerning vocational choice (e.g. San Antonio, 2016).

Despite significant differences found, this research had several limitations that should be mentioned. First of all, the participants for the research were chosen according to convenience (instead of random order). That means, the results cannot be applied to whole population in rural areas. The second limitation is related to the methodology of the study. Although the socio-environment factors which were provided to participants were theory-based (regarding works of L. Jovaiša, S. Kregždè, S. Daukilas, K. Pukelis and other researchers in the area of vocational orientation and purposefulness), however, future research should consider the standardized instruments to measure socio-environment factors in deeper and wider approach.

In conclusion, this research is an attempt to show the importance of socio-environment factors for vocational decision making of youth in rural areas. This is important because the most significant predictor of the return in rural region to work or practice is rural background of young people (Walker et al., 2012). The results of this study revealed that socio-environment factors are important for the purposeful decision making on the vocational choice of youth in rural areas. According to A. Amalba and colleagues (2017), the desire and willingness to work in a rural community combined with good communication and excellent interpersonal skills as well as good leadership skills are attributes of good role modeling that could influence young people's career choice during community-based education. Finally, the future research should to compare the socio-environment factors in rural and urban regions.

\section{REFERENCES}

1. Adamonienè, R., Daukilas, S., Krikščiūnas, B., Maknienė, I., Plujanskienė, A. 2004. Profesinio ugdymo psichologija ir pedagogika. Indra. [In Lithuanian]

2. Amalba, A., Abantanga, F.A., Scherpbier, A.J.J.A., Van Mook, W.N.K.A. 2017. Community-based education: The influence of role modeling on career choice and practice location. Medical Teacher, Vol. 39(2), pp. 174-180. https://doi.org/10.1080/0142159X.2016.1246711

3. Chiritescu, V., Ruxandra, A.D., Mihaela, K. 2015. The role of youth in sustainable development of Romanian rural communities. Romanian Economic and Business Review, Vol. 10(2), pp. 183.

4. Jovaiša, L. 2009) Profesinio orientavimo ir konsultavimo psichologija. Vilnius. Agora. [In Lithuanian]

5. Kojo Edeme, R., Akpotohwo, F.C. 2016. Enhancing youth employability and entrepreneurship within the local labour market: the positive youth model as a panacea. Journal of Academic Research in Economics, Vol. 8(3), pp. 386-397.

6. Kregždè, S. 1988. Profesinio kryptingumo formavimosi psichologiniai pagrindai. Kaunas: Šviesa. [In Lithuanian]

7. Lee, H., Lee, G. 2015. Getting On, Getting Out, and Going Places: Education, Opportunity, and Social Mobility in Nineteenth- and Twentieth-Century Rural New Zealand. Rural History, Vol. 26(2), pp. 227-248. https://doi.org/10.1017/S0956793315000059

8. Mubarakshevna, A.Y., Kasymovna, M.L. 2014. Factors Influencing the Career Choice of High School Students (Case Study of the Republic of Tatarstan). Theory \& Practice of Social Development, Vol. 19, pp. 1-3.

9. O’Neill, B. 2013. Success and Sustainability in Rural P-12 Schools Defining a Successful School--Queensland Style. Australian and International Journal of Rural Education, Vol. 23(1), pp. 61-74.

10. Pukelis, K. (2004). Mokytojų rengimo idealinio modelio parametrai. Kaunas: Spindulys. [In Lithuanian]

11. Rao, P. E., \& Rao, G. J. (2014). The role of youth in rural development. International journal of multidisciplinary advanced research trends, Vol. 1(2), pp. 53-57.

12. Sajienè, L., Antanaitiené, A. 2012. Tikslingo profesinio apsisprendimo skatinimas šiuolaikinejje socialinio ugdymo paradigmoje. Tiltai, Vol. 2, pp. 71-83. [In Lithuanian]

13. San Antonio, D.M. 2016. The Complex Decision-Making Processes of Rural Emerging Adults: Counseling beyond Dualism. Peabody Journal of Education, Vol. 91(2), pp. 246-269. https://doi.org/10.1080/0161956X.2016.1151749

14. Simões, F., Meneses, A., Luís, R., Drumonde, R. 2017. NEETs in a rural region of Southern Europe: perceived self-efficacy, perceived barriers, educational expectations, and vocational expectations. Journal of Youth Studies, Vol. 20(9), pp. 1109-1126. https://doi.org/10.1080/13676261.2017.1311403

15. Walker, J.H., Dewitt, D.E., Pallant, J.F., Cunningham, C.E. 2012. Rural origin plus a rural clinical school placement is a significant predictor of medical students' intentions to practice rurally: a multi-university study. Rural and Remote Health, Vo. 12(1908), pp. 1-9.

16. Yao, H. 2017. How Socio-Emotional Support Affects Post-Compulsory Education Decisions in Rural China. Comparative Education, Vol. 19, Iss. 2, pp. 33-63. 